\title{
The Purification of Ben Matthews
}

They were not the first alchemists or would-be alchemists I'd met in my life. There was Cov, for example-my much older, collegeaged brother-who was reading Jung's Mysterium Coniunctionis and had deemed himself white enough of heart to attempt the initial transmutation. "I am the man of lead; I am undergoing intolerable violence," read one of Cov's journal entries back then.

Nor were they the last would-be alchemists. I will not, for the utter shame of it, quote the agonized diary of my own teens and early twenties. I, too, fancied myself an arrow of pure longing, a pure beginningless vector pointed in the direction of the beloved. It may not have been until many years later that I fully understood amongst the complex stratagems of purification the role of unrequited love, that terrible apprenticeship-how, for example, the boy whom I loved at eighteen was in his disdain for me guaranteed to do for me what I could not do for myself: utterly eradicate my heavy, burdensome selfhood until I, even I, was ultimately shredded into small unimportant bits of light massa confusa, the essential chaotic building material of the universe-but even back then, at eleven, before unrequited love, before love, even, I understood the basic principles of the Work: Visita Interiora Terrae; Rectificando Invenies Occultem Lapidem. But this is not the story of my purification, but that of Ben Matthews, which happened at the silken hands of my Aunt Jannika.

There they were: the Happy Homeschoolers, as I'd dismissively called them once in a conversation with my aunt Jannika-Ben, the oldest, pulling Sarth, the youngest, in the red metal Radio Flyer wagon up and down the streets of Cambridge, Violet and Julia walking animatedly alongside, their backpacks lumpy with books; it was the Matthews family out and about, having finished their Saxon Math for the day and now doing their thing, which happened to be the study of alchemy that summer. Ben was sixteen, five years older than I was, Violet was twelve, Julia was nine and Sarth, five. Mere gold was not their aim (as Violet informed me, munching on cheese 
crackers as she walked). They sought, rather, nothing less than to produce the glorious and multiplicative philosopher's stone and to use it for Universal Good.

Whatever. They were not naïve enough-not even, I think, was Sarth, at five, so naïve-to think that Universal Good would be easy to figure out. Still, I liked their ambition. I both liked and was irritated by their well-trained minds: they were being homeschooled in the classical method of the Trivium, which made my own "unschooling" sort of homeschooling seem rather foolish and insubstantial. Ben, for example, was at sixteen making his way through the Middle Ages for the third time, this time using original sources. At this point he was also pretty much in charge of teaching the others. "So, this girl's name is Surtsey," he said to Sarth instructively on that first day we met. "Surtsey is the name of an island off the coast of Iceland. It was created by an undersea volcano back in the sixties or seventies. They named it after Surtur, an Icelandic goddess." He looked over at me for corroboration.

"Sixties," I said crisply.

Ben nodded. I could tell he was making a mental note of it.

Wolfi, when I mentioned the meeting to him the next day, said, "You can't spend much time with the Happy Homeschoolers without noticing what a fantastically unironic and grateful group of clucks they are. Never were four kids together more inclined to pass up or fail to recognize opportunities for sharp retorts, eye-rolling, and sullen responses. Never since the Boxcar Children has there been a group containing a teen and a preteen-not to mention a group containing four siblings, the younger of whom were in the care of the older-never has there been a group so confected that was less sarcastic. "I think I'm quoting him right. I think, to be honest, that he admired them more than a little bit. But Aunt Jannika, who'd met the parents at some reception at the A.R.T. (she's an actress) said, simply, over her shoulder (she was heading out after having dropped by with Wolfi for a coffee), "Talking with that family is like cooking a meal with dull knives."

What a liar that Jannika was. What a dissimulator. ("Of course," said Jannika to me last week when I reproached her yet again about those days. "Of course." She shrugged her shoulders. "I had to lead you off the track.") There is a nightmare that Jannika has had many 
times in her life; each time that she has fallen in love she has had it, and she'd had it the night after that reception at the ART. She was in a house and the house was being violently broken into. Someone outside, someone large and strong and angry, was crashing through the wooden walls with an axe. The steel metal of the blade was forcing its way obscenely through the door-panels. Jannika was beyond screaming. The wood splintered. Again it splintered. The fan-glass detonated and a fountain of sharp glass points precipitated upon her, glittering like a thousand twisting crystals. She woke up at that point, sobbing with fear. Something was exploding darkly in her head and throat and chest; it was her heart. Who is it? she knew by then to ask herself, gasping. Who is it?-for it had happened so many times that she knew by then the meaning of her nightmare. Who is it that I love? she asked herself. She cast her mind around the usual suspects and then the unusual for the soul whose presence must have just begun to trouble her equilibrium. That night, come alert to herself in a twisted tangle of bedsheets, soaking wet and choking on her cries, she knew immediately and with a secret thrill of transgression that it was, this time, that boy, Ben. She thought of the way he'd kept his eyes on her that night. He'd blanched when she approached him. His body was so slim and reedlike; his arms were outgrowing his sleeves and the wrists had looked so white and naked poking out from the cuffs. She was moved by the reckless clarity of his desire for her. Even the air around him had seemed to rock moistly, concentrically, with the wavelets of new love, like a still pond into which a stone had been casually, even carelessly, tossed, with the most extraordinary and irreversible results. Oh, she sighed aloud. Wolfi, alongside her in the bed, put his big-sky arms around her without speaking and pulled her close, breathing slowly and powerfully until her heart stopped knocking and her body and hectic mind were slowed. She allowed herself to be nestled in his embrace like a spoon in a spoon. Her eyes were closed and she was still, breathing deeply and regularly. You would have thought she was asleep. Wolfi, holding the moist silk skein of her body in his, thought she was asleep. But there was a tiny glowing image she was feeding with shred after shred of tinder-an ember of a thought she was cosseting secretly as you would cosset a perilously-struck match in your cupped hands. Ah! Look! Her face was aglow in the tiny red light. 
Ben's first sight of Jannika: a slim girl-woman wearing a long darkgreen dirndl made of some glossy stuff that caught the light when she moved across the room. She'd reminded him of a mermaid. Her hair was dark gold and heavy; it hung halfway down her back and the ends were crisply cut. She came close, carrying a crystal wine glass filled with transparent liquid. She saw Ben staring at her, and she tilted her head to the side, crinkled her nose, and smiled back. In each of her ears a small diamond dangled on the tongue of a tiny silvery bell. Her skin was pink and fresh and though she was old - Ben realized this at once; she was thirty or more (Ben was sixteen)-Ben wanted to pull her close to him and kiss her. Ben, standing round his parents and his three siblings, discussing something-the theme of Wolfi Finn's new play Singly Goes My Doppelgänger, the President's latest South Asian policy, the results being beamed back to earth of the Hephaestus probe-Ben, fatally distracted, suddenly tripped. His mother darted a compassionate look at him-she was catching it all; she'd missed little thus far in the life of her first-born and she'd been expecting love to befall at any moment; it would, she knew, be the next big thing-but Ben glared at the floor as if to blame for his clumsiness a cocktail napkin someone had carelessly dropped beneath his feet or a crack in the floor tiles or a slippery puddle of someone's spilled martini: anything, anything but acknowledging the truth: that in his profound new state of being he had suddenly forgotten how to continue to stand.

Oh, he looked up miserably then and though he wanted to look anywhere but at the golden girl-woman, he could not help lifting his eyes to glance once again at her face (his mother, her heart breaking open at once with a sudden revelation of her own mortality, her own inevitable death, as if something had suddenly bloomed in her-the large fragile-petaled flower of an idea which had been set astir at the moment of her first taprooting into the solid core of the world sixteen years ago when the infant Ben, placed upon her belly, had first suckled at her nipple-O my son, my son-put her arms around her husband and squeezed, and her husband looked up, interested, his face suddenly as charmingly pixeled as a refreshed computer screen, and another woman nearby in the room, noticing that attractive man whose skin was rosily bedewed and whose features were floodlit with galvanics, touched, with a soft-stroking manicured finger, the dinner-jacketed bicep of the man beside her.... What a circle of 
misplaced ardency there grew at that moment, like a rose-lit tongue of flame licking its way swiftly around a ring of soul-longing dolls!) and there she was, Jannika, Ben's beloved (he knew it at once; in an instant he was no longer a child and no longer thought as a child) looking back at him candidly, curiously, her lips half-open. She was about to laugh. She was laughing.

And so it happened that the next morning Ben, in his family's kitchen, was single-mindedly plotting the next step of his first amorous adventure. Ben never drank coffee, but that morning he had already finished off the couple inches left stewing in the black Krups coffeemaker when his parents left for work, and he had located the bag of beans on the shelf to grind enough for another pot. Sarth and Julia, sitting on the high stools at the counter, were in the kitchen, too-Sarth watching him with the intent look of a boy who loves activities that involve intricately-calibrated machines, and Julia, who had Little Women spread open in front of her, not paying attention at all.

"Smell," said Ben to Sarth, and held the open bag below Sarth's nose. The beans were dark and oily; their smell filled the kitchen.

"It smells like peat moss," said Julia, looking up for a moment. There were tears in her eyes; Beth March had just died.

Ben poured some beans into the grinder, pushed his thumb down, and the machine ground loudly for about thirty seconds. When he pulled off the plastic lid there was a grainy dark-brown powder spilling over the edge onto the countertop.

He estimated that each cup of water he added to the coffeemaker must need about three or four round tablespoons of the ground beans. The coffeemaker gurgled in gratitude. After downing a couple of mugs of his concoction, everything around Ben had a pronounced purple glow, but his thoughts were stunningly clear. This is what he would do today: he would head off Jannika when she was on her way to the ART for rehearsal that morning. He would avow his love. It never occurred to him to do otherwise. You fall in love, you proclaim it. It's a homeschooling thing.

"Jules, you tell Violet to take over today, okay?" he asked.

"Mom and Dad know about this?" she asked. She wiped the tears from her right cheek unashamedly with the back of her right forearm. 
"They don't need to know. This is personal."

She put her head down in her arms, sobbed loudly once. "Whenher voice muffled-when will you be back?"

"I don't know. Probably by dinner time."

"Okay; okay," she said. And then, her face still hidden in the ring of her arms, her words wet with the mourning of poor, dear Beth, "Good luck."

But Jannika was not alone when Ben found her. She was walking down Mt. Auburn Street alongside someone, a man. This made too many men present for the kind of encounter he had in mind, and even though all of Ben's senses had leapt to attention at the sight of her, he now hesitated for a moment. Was this man her lover? The man was wearing leather and Lincoln-green clothing. He had a worn leather backpack on his back; he had a torso rather like a tree trunk; he looked rather like a large elf might look. His face was coming into focus now: he had broad high cheeks-reddish cheeks-and eyes like almond slivers. His eyes looked like they'd been narrowed by years of laughing, and Ben recognized him suddenly from some newspaper article or theater catalog. It was Wolfi Finn, the playwright. People said he'd written his new play specifically for Jannika. Ben's heart sank. They were lovers, of course. He himself was a fool. He saw that Jannika was laying her hand on the man's arm and leaning in towards him as they walked. They were giggling. Ben spun around-not necessarily to give up his plan, I should say; he was simply going to reschedule, replot, regroup-but Jannika had seen him and recognized him (and how grateful Ben would have been if he could only have known that the wetness of sex flooded through her body at that moment.)

"Young man!" she cried out.

Ben turned around reluctantly.

"You were at the reception last night."

Ben didn't say anything for a moment. Then he lifted his head up slowly and looked directly at her. He said to her, "I came here to find you. I want to talk to you. I love you." If he was a fool he was going to be a bold fool.

There was a silence for a moment. Then the man said with a booming laugh, "Well! Well done you! You're a courageous sprout!" Ben was not going to respond to that, not even indignantly. His eyes 
had found the spot in the center of Jannika's pupils, and it was like a hole to hide in.

Then the man said, with recognizable kindness in his voice, "I shall leave the two of you alone to talk about this," chuckled (despite his generous intent), and vanished down the street. There was silence for a long moment. Ben died a thousand young hero's deaths until Jannika spoke at last.

"I know," said Jannika. "I could tell last night."

Ben looked at her face then. "I guess a lot of men have fallen in love with you."

"No," Jannika said, unconvincingly. "Not such a lot of them."

Silence for a moment.

"At least, not such a lot of boys."

Ben looked like she had hit him.

"Let's get everything out on the table here," she said. "I'm thirtysix. I'm living with Wolfi Finn. I'm an actress. How old are you? What do you do?"

"Sixteen." He didn't even think of adding a few years. "I...I study."

Jannika laughed. "Okay," she said. "What are we going to do about this?"

Ben suddenly realized everything that Jannika had not said.

"Oh, everything," said Ben. He started to smile at her, and she started to smile back. It was their first mutual smile. "Everything that people do when someone says they are in love."

"Oh?"

Believe it or not, Ben's parents, in their earnest homeschooling way, had been giving him lessons in dating (though it's not in the classical trivium!) since he turned thirteen. A couple of times a year his parents collected together some single friends of theirs of various ages, each of whom invited a date, along with Ben, who asked a girl-usually, but not always, a homeschooling girl-and they went out to Christopher's or some place like that for a drink (seltzer in the case of Ben and the girl) and dinner, and then, say, to a movie at the Brattle or the Harvard Film Archives. Another time it might be the Algiers for coffee or The Oblique Moon for China tea and sesame crackers. The very first time, Ben had to bring the second girl he asked, but asking and being rejected and having to ask someone else had been, his parents had assured him, part of the lesson he 
was meant to learn. Somehow no one had turned him down since and, indeed, if Ben had been graded for any one of these evenings he would have received an A: he'd been warm, thoughtful, clever, amusing. Even the older men's dates had thought so.

"We could go for coffee, for starts," said Ben. "Will you come for a coffee with me? This afternoon?"

She was charmed by his sudden freshet of confidence.

"Please?" he said. "I'd simply love to have a coffee with you."

She couldn't go out with a sixteen-year-old. "Listen, I've got to get to work now," she said.

"Of course," he said stiffly.

She wanted to reward his courage. And there was, as well, the matter of her dream last night and her desire to touch his skin.

"Oh, okay," she said. "Just this once. I'm free at about three."

"Good!" said Ben. "I'll come by the theater to walk you into the Square." He saw her measuring this idea. "Or how about this? Do you want to meet at the Algiers? Three-ish?"

Somehow she nodded. What could she have been thinking of?

"I have a nephew just three years older than you," she said when she joined him that afternoon in a corner settee at the Algiers. Her hair was wet; she was pushing the spiraling tendrils from her face. It had begun to rain gustily outside-a nor'easter was brewing-but here it was warm and dark and still as a cave. The walls were covered in lacy wooden filigree and the doorways were arched. On each little table a candle glowed in a red glass globe. Some grad students nearby were smoking clove cigarettes, a smell that Jannika loved.

A waitress was standing beside their table and Jannika stopped speaking.

"What would you like?" asked Ben.

She thought for a moment. "A mocha latte," she said.

"A good drink for a day like this," he said, and she felt absurdly pleased.

Ben turned in his seat to the waitress. "A mocha latte and an espresso," he said to her. And then, to Jannika, "But wouldn't you like something to eat, too? They have a good hummus here."

What a nice boy he was! "Yes," she said, shortly. "Why don't we share that?" 
"Hummus for the table," he said to the waitress, who nodded, suppressing a smile. Then Ben turned back to Jannika.

"Your nephew," he said. "Yes. But age is relative, don't you think?" He'd planned all afternoon to make this point. He could see her weighing that one, and he rushed on. "Would you like to go a movie with me tonight? There's no performance tonight, is there? The new Herzog is at the Film Archives."

"I can't go to the movies with a sixteen-year-old."

"Why not? It would be fun to talk about the movie afterwards. Do you like Herzog?"

"Some of my friends will be at that movie. Yes, I like Herzog."

"We'll go late. We'll sit in the back." He paused. "I don't want to embarrass you," he added earnestly. "I just want to spend some time with you. I've never felt this way before."

She remembered her dream that night and blushed. She already knew that it was inevitable. They would meet at the film archives and they would touch, at first as if by accident; their hands would brush against each other in the dark of the theater. On the dark paths home one of them would pull the other into the shadows, and they would kiss. The smell of cloves and chai and the darkest coffee was swirling deliciously around her. The music had gotten richer, its essences more minor, more deliriously spiced. This bold boy would be the one to reach for her in the darkness of one of the paths. It would be out of her hands. Inadvertently she sighed.

Ben looked up, hopeful. Jannika was staring at the little golden wick in the red glass globe. Her right hand was palm-down on the table top.

"No one can ever know about this," she said.

He put his hand out, touched the back of her hand, and then immediately drew his own hand back. "Oh god," he whispered.

"No one can ever know about this," she repeated.

"Of course not," he said, still whispering. Then he straightened up, leaned back. The waitress had arrived with their coffees. "Of course not," he repeated, more casually. Now the waitress was gone from their dark corner. "I love you," he said quietly. His mother, at her lab at MIT, put her hand to her breast. There, for just an instant-she'd felt that pain again. 
Blessed was the new world of the lover and beloved. Blessed was he who wore his heart on his sleeve; blessed was Ben, who trembled against Jannika that night below a rain-soaked cherry tree, under a canopy of deep rose-colored petals glowing stainedly in the light of the streetlamp outside the Carpenter Center. Each curved cherry petal was spilling over like a tiny little dipper, spattering warm rain from the afternoon's downpour, and in all of this popping, liquefactious air he'd backed her against the dark black trunk of the tree in a dark copse of trees. He'd pinned her between his two straight arms and then he'd leaned in and kissed her as if he'd kissed a woman before (he hadn't).

Her body strained forward, meeting him more than halfway. He was shocked to his center when he felt rising against his chest the tumult of Jannika's own body, strong and elastic in its butterfly wisps of clothes. He was pinning her arms back against the tree now, holding them up high above her head; his hands could easily ring round her little wrists. She was reaching for him with her body, battering herself against him. He kissed her again, and then, more deeply now, again and again, slowly tasting her and being tasted. Now she lifted her throat to him. It was fragrant with smooth round vanilla, and with the pointier molecules of orchids and tearoses. He followed the lineations of flavor down with his lips to the base of her neck, to the frail sepals of her neckline, above which he buried his face. Below his lips now her breasts were growing rounder, fuller, taut; her heart was pounding against him. Glory, he thought brokenly. Glory, glory, glory. The world was richly saturated with color and fragrance and the intoxications of skin. He pressed himself against her. She raised one of her long legs and wrapped it around him.

And then, suddenly and with no warning whatsoever, as if at some mysterious signal, the tree suddenly let down all its flower petals at once upon the two of them, like the dropping down of a rose-figured curtain; the air was filled with rain-heavy dark-pink petals; they swirled and plummeted and the sky was obscured; you couldn't see beyond the world of petals. The petals landed upon their hair and shoulders and moved in slow tracks down their clothing and limbs. Jannika and Ben were transfixed; they stood beside each other now without touching, their arms dangling at their sides like the arms of stick-figures-so bewildered and moved were they by the beauty, 
the strangeness of this benediction by tree. In a moment it was over, and the whole soft burden of the tree lay at their feet. Above them the branches waving before the street lamp were brown, bare of flowers. Ben-he couldn't help it-fell down to his knees then and sobbed, sobbed with great wracking coughs, and Jannika, momentarily taken aback, looked down disaffectedly at the petal-streaked boy at her feet who was making such great choking sounds, crying like a great big baby who'd for the first time been overwhelmed at the beauty of the world. What a child he is, really, thought Jannika then. But how like Wolfi he is, too.... In a minute Ben's sobs quieted and he slowly stood up. His face was empty. He moved towards Jannika, and she, thinking he was going to kiss her, opened her arms dutifully, a little bored already by the whole thing-but to her surprise he moved past her like someone sleepwalking, he seemed scarcely to see her, and he kissed instead the black coruscated bark of the trunk of the cherry tree behind her. Jannika, who'd turned to watch him, was delighted. This was something new. She looked at the brown thatch-like hair on the back of his head, and looked at his large hands-they were softly, tentatively, touching the slender trunk of the tree. Then she heard a sound; he was chuckling, he must be chuckling, and he turned around to her, and yes, he was smiling broadly, and then, as if it were all the greatest, most delightful joke, exploding into mischievous laughter.

She burst into laughter too and swooped down on him, knocking him off balance and falling with him so that they were both lying together on the ground and he was beneath her now on the wet, blossom-littered grass. She straddled him neatly and the silk skirt of her dress draped him in a soft circle. In a swift movement he immediately unseated her, rolled her over, and straddled her, and now-how she wanted him now; how ready she was-he kissed her again, first her throat, and then her silenced mouth, and she was soberly, systematically, kissing back. She closed her eyes. His lips were strong. He was using his teeth artfully to pull down the top of her dress. She could feel him taste his way down her breast, and then she could feel, my god, the stiffened muscle of his tongue as it dragged across one of her erect nipples. She opened her eyes and saw only the brown swirling crest of his hair. His hands were deep inside her dress, under her skirt, spanning the bare skin of her waist. He lifted his head for a moment, his eyes flickering up to 
hers impersonally; his face was an empty carapace; he had gone far inward. She flickered her eyes across his, semaphor for yes.

Blessed is transgression, the breaking of the taboo of age. Blessed the breaking of the Eagle Scout into tiny, tiny, tiny little pieces, and the severing of boy from family. Blessed the creation of the massa confusa, the raw stuff of the universe, the molecules of alchemy. It was Jannika's (though I like to think she didn't know this) most devastating performance.

The next afternoon, dazedly pulling Sarth home from his Suzuki violin lesson at the Longy School, Ben, accompanied by the whole Happy Homeschooler entourage, passed in front of the display window of China Imports on Mass Ave. In the corner of his eye he caught a quick glimpse of something amidst the dusty clutter of porcelain chinamen with bobbing heads, domed woven-grass hats, pleated paper parasols, and filigreed sandlewood fans-something pink. It was a spray of artificial cherry blossoms. He stopped short.

"Hey!" shouted Sarth. He'd been riding in the Radio Flyer wagon with his legs outstretched in front of him, and the sudden halt had brought his forehead nearly to his knees.

The flowers were the same deep cherry color as both the petals and Jannika's dress had been and, like them, were flushed with the palest salmon. For the hundredth, no, for the thousandth time that day the startling new sensations of the night before flooded over Ben. It was too much; he had to look away. At that very same moment a bright pink VW Beetle drove past them, slowly enough that Ben could glimpse a pink flower in the dashboard bud vase. Without thinking, Ben immediately broke into a gallop down the street after the car, still pulling behind him the wagon holding Sarth.

Sarth let out a long shriek and then, hanging on tight with both hands to the low metal rim of the wagon, shouted, "Yeah!"

"Hey! Where are we going?" shouted Violet, stampeding alongside.

"That car! Follow it!" shouted Ben, who knew only that cherrypink meant love, meant Jannika.

"Why?" shouted Julia, running just behind the wagon.

Ben turned his head around briefly, without breaking his pace. "I'll explain later," he panted. He rushed on pell-mell. 
But the car was moving away from them. By the next intersection it had sped forward in advance of the red light, and was gone. Ben had never even seen the driver. He ground his heels into the pavement to stop, and the others piled into him; here on Maughm Street, which cut across Mass Ave., the traffic was streaming earnestly, seamlessly. They waited for a walk signal.

"Well, Ben?" said Julia, breathing hard.

"Actually, I can't explain," said Ben, looking down at the ground. There were leaf imprints in the concrete. "It's important, is all." Julia looked through her lashes at Violet, who looked guardedly back. They'd discussed Ben earlier that afternoon in a secret powwow in Violet's bedroom. What time had he come home last night? What was the meaning of the smug and unendurable smile that had been plastered across his face all morning? They had their theories. When the light finally changed Ben didn't move. He was feeling, for the very first time of his life, irrecoverably lost at an intersection; he simply didn't know which way to go. He didn't know whether to go. He was awaiting instruction. The others waited beside him without speaking for several long minutes. The light was going to turn again. But then a butterfly fluttered past, heading across the zebra stripes towards Garfield Street. The butterfly was pink. "That way!" shouted Ben, yanking on the yoke of the Radio Flyer and setting off at a careening pace across the road. He bumped the wagon up over the curb and clattered it desperately down the root-damaged, crazed-cobblestone sidewalk.

"Rock and roll!" shouted Sarth.

In a few minutes the butterfly had disappeared. It was replaced by a bicyclist in pink overalls on an old Raleigh three-speed, and then, three blocks later, by a white dog who stopped to snuffle at the group before trotting down Oxford Street-her collar, poking through the soft fur, pink....

In this way the homeschoolers orienteered through the entrance doors of the Peabody Museum, up one flight of stairs past the guard desk-Violet insisted on pulling from her back pocket the family Harvard ID card and flashing it at the guard, who was, as always, trying to wave them through, he knew them so well-and then up the next flight to the exhibit halls. Ben was impatiently pulling Sarth up the stairs by the hand, and Sarth, who'd preferred the race on the Radio Flyer, was on the one hand pulling back from 
Ben and, on the other, securing indescribedly-delectable pleasure by loudly stomping on each one of the marble steps with his big, loose, leather Christopher-Robin boots. The echoes were gorgeous. ("Slow down, Ben, for heaven's sake," said Violet. "Sarth, be quiet!") And then, there, standing right before them, surrounded by glass flowers-and forever confirming for Ben that the universe was constructed just so, along the sliders of mysterious tectonic plates, and that the clues could be recognized and heeded if you had the eyes to see and the will to follow-stood Wolfi Finn in his clothes of leather and Lincoln-green and alongside him-Ben's heart nearly stopped-Jannika: their foreheads together, talking low. Ben took in the whole scene with a glance. Wolf held Jannika's fingers loosely in his two hands. She was wearing a narrow gold dress today, several shades darker than her hair.

Wolfi and Jannika looked up.

"Well, well," boomed Wolfi. "It's that lad, yesterday's lad, come a-courting again, I expect." He smiled kindly at Ben.

Violet and Julia turned round to Ben and stared, both their mouths hanging partially open. Jannika smiled slowly, like someone not quite understanding. The edges of her face were soft. She looked, thought Violet, who, somehow sussing her importance, had turned back towards her almost immediately to examine her critically, uncharitably: the woman looked old. But to Ben, catching it all gratefully and getting it-the sleepiness of Jannika's face, the skin like blurred creamery butter but the sharp intellection of her clothing - she looked like an immortal, like a marble caryatid in a golden gown. The sleeves of her dress were narrow and extended in a point to the middle of the back of each of her hands. The hem flickered around her ankles, just above gold Grecian sandals. She'd pulled her hair back into a long bound ponytail, crisscrossed with golden ribbons. Ben stepped forward, deliberately breaking into the magic circle of Wolfi and Jannika. Possession is nine-tenths.

"Yes," said Jannika. She bestowed upon him a secretive smile. "Ben."

It was a special voice she used, and the intimacy of it was unmistakable. A kind of shock wave moved outwards from her and curved dangerously over all of their heads. Even Sarth felt it; he looked upward at Ben with sudden renewed respect. 
Wolfi reeled. He stared at Jannika and then at Ben. "Good lord," he said quietly, almost whispering, his eyes on Jannika's face. "You...." He turned then and strode away from them quickly, his Finnish boots padding loudly across the floor. At the far wall he turned and addressed Jannika with a terrible, carrying quietness, his voice cold and precise: "You two will want to talk. And I shall go walk around." The muscles in his face were working. "You and I, Jannika, will talk at home. I think that there is a lot we need to say to each other now." He turned now to the three other children and walked towards them. "Okay, little man," he said, singling Sarth out. He smiled painfully, unconvincingly. "Would you like to see an animal that looks like a pinecone?"

"The pangolin," broke in Sarth, Julia, and Violet all together. Jannika and Ben were gazing at each other. Wolfi glanced at them, winced, and looked away.

"We know the pangolin very well," said Julia to Wolfi. His height, she saw, had seemed to diminish visibly in the last few moments.

"It's our favorite animal," Violet added. "At least, it's the favorite of three of us. Sarth likes the gorilla doing the chest punch best." Sarth obligingly punched his chest with his alternating fists and produced a series of loud hollow thuds. Violet looked sternly down at him and he stopped.

Wolfi's face was etched with vertical lines. Tactfully, Violet said, "Let's go see the pangolin again. It's been a long time. Would you lead the way?"

They left in a slow, courtly, and disdainful procession, only Julia hanging back. Ben immediately stepped towards Jannika and put his arms around her.

"I love you," he said. He was going to kiss her, there amongst the cases of glass flowers, there in the sight of god and the public-and in the sight and hearing of Julia, too, who was secretly peering at them from the next room, through the reverse lettering across the double glass doors, her ear to the slit.

"Ben," Jannika said. He stopped and looked up at the tone of her voice. "Ben, last night was lovely. You are lovely-"

"Oh, Jannika, you-"

"No, listen, Ben. Dear one. Listen. You are an extraordinary boy, but-"

But, as it turned out, it was over. 
Now begins the night of the soul, the dark wind that swirls around and around, the dark wind that enters in. Damned are those with their hearts on their sleeves, who love, as Ben loved, without any armor, without even the padded sark of irony. Julia, outside the glass door, was sobbing for Ben now-sobbing as if her heart would break. When the others returned, Ben was gone, the doors had already stopped swinging, and Julia was on the floor, hugging her knees tightly, her face covered with tears. "Julia!" cried Violet. "What_-" But Julia never said.

Of course he tried everything. Jannika must understand the depth and the endlessness of his love! At Pearl Paint he bought, to the tune of fifty dollars-though he'd have paid anything. What did it matter? What did anything matter? - a booklet of gold leaf. How beautiful it was: the square glassine envelope holding a stitched signature of soft pink paper: the pages were interleaved with the small square sheets of gold, each square glittering and frail, a mere molecule thick and as responsive to touch as if it were a living thing. She would understand. She would be overwhelmed. He mailed it with no additional message to her address and waited. His arms were lifting all by themselves and molding themselves around empty air. "Jannika," he cried into the darkness, kissing his pillow. He imagined her smiling back at him through the dim light of his bedroom. There was some mistake, is all. He would not phone her, he would not trace her path to the theater and back, but one day he came upon Jannika in the Square and his face broke open with eagerness and hopefulness and relief. She turned crisply away. Ben, whose soul sizzled its tethers at that moment, etherized, and escaped, froze in place. He stood there for over an hour, stunned; he could not will himself to move. Pedestrians walked around him, couples breaking apart to pass him on either side. A cat nuzzled at his ankles and went on, disinterested. A pigeon landed nearby, investigated, departed. Then: "Hey, Ben!" shouted an acquaintance from a car window: Ben found his legs shifting again. He was walking. He was walking faster and faster. She would love him. He would make himself worthy. He ran down the street now in a determined frenzy. It was himself he pierced that night and then again night after night at archery practice on the river bank, aiming at, and striking, the smallest circle in the center of each of the row of straw-stuffed tar- 
gets. He pulled from his quiver the next slender arrow and fitted it into the recurved bow. "I love you, Jannika. I love you! I annihilate myself in my love for you!" Jannika was, apparently, unmoved.

"Ben," said Julia, bringing to him, pathetically, a columbine from the wild back garden, a mineral from the Museum of Science. "Listen, Ben"-she played for him a new tune on the recorder. He sat there in the chair. Sometimes his eyes were closed and sometimes they were open. It was all the same. "Ben," said his mother. "Son. Ben." All they could say, really, was his name. You are Ben. You, Ben, are. You exist still, remember? - for he was emptying out before them all. "She hasn't taken your soul, you know," whispered Julia to him one afternoon. Ben opened his eyes vaguely and closed them. For of course she had.

A week. Two weeks. Three weeks, and now, out of the blue, over a span of twelve days, a one-hundred-and-sixty-hour flurry of activity: Ben was building for Jannika a model of the Matthews house. He could not have said why; it was simply something he found himself doing.

The house itself, the real house, that is, was a vast and shabby Victorian right outside of Harvard Square: the homeschoolers had grown up in the repaired remains of one of the old grad-student communes of Cambridge. Across the front porch there was still a long hand-carved sign that read: Center for High-Energy Metaphysics. At the side of the carriage house at the end of the driveway there was a smallish but very solid round door on thick wrought-iron hinges. There had been a thriving little business there in the early computer days (Altairs and Lisas and early Apples) and that sign remained, too, carved in a curved arc above the circular doorway: Hobbitware, Hard and Soft, it read. The two big barn doors of the carriage house, facing the driveway and thus the street, were still painted with an enormous peace sign; it was a kind of landmark and Ben's parents felt obliged to freshen the sign with new DayGlo orange paint periodically. My own parents, like a lot of people, probably, couldn't walk past the house without commenting, ruefully: "We could have bought this place for a song in the eighties." I'd heard them say it a hundred times. "A song. Just a song. On TA stipends we could have bought it." For many years during and following the Vietnam era the house had been used as a base for a large population of draft-dodgers who'd lived statelessly, with thousands 
of books and without the usual papers, amongst everyone and in the midst of everything in the Square-an open secret, highly tolerated by the liberal Cambridge set. But then, after President Carter and the draft pardons, the house had perpetually been for sale until Ben's parents, cleverer than most, perhaps, and apparently singing that little song, had up and bought it.

The model of the house was one-twelfth scale, which still put it well over three and a half feet tall. Ben's father and Ben had measured and scoped the real house and drafted the model plans together almost a year earlier as a homeschool math/art project. They had cut all the framing wood and the shingles, and, on a jigsaw, had pre-drilled all the scrollwork detail. It had all been good to go then, and the girls had started painting sprigged wallpapers to photocopy onto high-cotton resumé paper for the dining room, living room, and bedrooms, and Sarth had offered to mold all the toilets out of Sculpey. In the end, though, the project had gotten put aside at that point, for some reason or another. What? Was it then that Ben'd gotten fired up about traditional archery and had built his great bow, joined the archer's league, and started spending all his evenings at target practice? Was it something else? - the grinding of lenses for the telescope? The discovery of the old James Beard Bread Book in the pantry and the subsequent Month of Bread? The glazing and then land- and water-scaping of the long, riverine aquarium? In any case the postponement was providential. Back then the making of the model had merely been a classic homeschooling project: interesting and educational and all that, to be sure. The homeschoolers might even have eventually followed the construction of the model with the construction of a real building, some pottery shed or chicken house or sauna to be architected and executed by the kids deep in the backyard, with Ben dutifully and responsibly presiding. Now, however, that love unrequited had uncovered in Ben all of the mad urgencies of a nest-making bird it was fortuitous, you could say, that in neat labeled stacks in the carriage house, on a table made of 8 ' by 16 " plywood laid upon sawhorses, the plans and wood were already prepared; they'd been long ready.

He dragged the finished house over to Jannika's apartment one warm afternoon, roping it atop the Radio Flyer. 
On the way over there'd been a small event, something for a mind as empty as his had become to turn over and over later on in the privacy of his room: Crossing Oxford Street from Sacramento a little girl holding her mother's hand had stopped to marvel at the dollhouse, and then quickly had opened her small dirty fist to show the house to the creature she held in there. Clutched in her hand was a small homemade fairy-something constructed cleverly of pipe cleaners, wool felt, and embroidery threads, with a skirt of petals pulled from an artificial silk flower. The hair was of soft yellow mohair strands, and she wore on her head an acorn beret. The fairy was about five inches tall, exactly the right scale for the house. The little girl darted forward her arm quickly, reached inside the window of the attic room-the very room which would have been Ben's attic bedroom at the top of the house-and neatly dropped the doll through the miniature sash.

"She's home now! This is her house!" cried the little girl.

"Oh, no," said Ben. He began to lift the roof to remove the figure. The little girl began to scream, a wild keening. "It's her house! It's her house!" Ben looked over at the girl's mother in confusion.

"Well, Clarissa is very opinionated," said the woman. "Why don't you keep the doll? Couldn't you keep her in there?" She turned to the little girl. "Are you absolutely sure, Clarissa? You know, you won't get the dolly back again."

The little girl had quieted down and was nodding slowly, calmly. Her eyes, blue ones, were large and serious and were focused for faraway; she'd attended, like a good mother, to the future.

Ben could hear the fairy rattling inside the bedroom as he bumped the wagon down the street. He stopped in front of the three-decker where Jannika lived and hoisted the house up the stairs to the front porch. Descending the steps a few seconds later with empty arms, he stopped for a moment, his head bowed. A soft breeze blew directly through him. He was dead now, he knew he was dead-and knowing with such clear certainty that he was dead he would, he understood, be able to live out, in some manner, the rest of his life. His lips tightened into a grim smile. He continued down the steps.

When Jannika got close to her three-decker she could see Wolfi walking around and around on the front porch, a coffee mug in his hand, looking down at something that was still, from her point of view on the sidewalk, concealed behind wooden railings, the 
landlord's azaleas and mountain laurels, and the draping wisteria. She walked heavily up the front steps. Her gynecologist had just confirmed that she was pregnant and among other immediate alterations to her psyche the news had invoked in her a new way of walking, as if she were already thick, belabored. The heavy silver coffee thermos was balanced on the porch railing; Wolfi would have left it there. Coffee was forbidden her now.

What Wolfi was apprising was an enormous wooden dollhouse, turreted, elaborately jigsawed, plunked down on the blue-painted floorboards of the porch. Jannika blinked. Wolfi spoke without turning to her. "Well, well," Wolfi said. "What have you done to this boy, Jannika?"

Jannika gazed down at the huge wretched object and in an instant, without having had to think, she had lifted the heavy silver thermos of coffee from the porch railing, raised it high over her head and then smashed it down on the roof of the house. Wolfi let out a cry of dismay and reached out instinctively to stay her arm. Jannika pushed him aside. The dollhouse roof splintered loudly and the house cracked open. "Jannika!" cried Wolfi. "What are you doing?"

Tears were spilling down Jannika's face, which was twisting like that of a girl who is grief-stricken on a stage, and she was lifting and bringing down the thermos again and again. Smash. Smash. Smash. Wolfi was momentarily repulsed. He scarcely knew this woman anymore. And yet (for he automatically enfolded her in his arms; she was crying and in the throes of strong feeling, and defenseless now, having let slip the thermos from her hand onto the floor) and yet he loved her, this Jannika, loved her as fiercely, I dare say, as she loved herself. Over the smooth yellow hair of the head buried now in the hollow of his shoulder he could see, inside the cracked walls and roof of the attic bedroom, the tiny rose-petal fairy. "Poor lad," said Wolfi. "Poor, poor lad. What will become of him?" He bent forward and kissed Jannika's hair. 